Matej Urbančič, Meta Kutin, Dušana Findeisen, Maja Mezgec, Nives Ličen, Klara Kožar Rosulnik

\title{
EXPANSIVE LEARNING AND RESEARCH PRACTICES AT THE SLOVENIAN THIRD AGE UNIVERSITY
}

\begin{abstract}
Several innovative projects have been conducted at the Slovenian Third Age University (U3A), creating important new social practices. The project results impact exploratory learning as well as learning and development in the wider community. The aim of the paper is to describe selected research practices at the Slovenian U3A and to interpret them through the theory of expansive learning. In terms of methodology, the research is designed as ethnographic research with elements of the phenomenological and reflexive research paradigm. Selected examples of exploratory learning at the Slovenian U3A are used to identify the factors that influence the development of exploratory learning and the way they are experienced by those involved in exploratory learning processes. It has been found that expansive learning at the Slovenian U3A leads to innovative and socially engaged practices.
\end{abstract}

Keywords: third age university, expansive learning, exploratory learning

\section{EKSPANZIVNO UČENIE IN RAZISKOVALNE PRAKSE NA SLOVENSKI UNIVERZI ZA TRETJE ŽIVLJENJSKO OBDOBJE - POVZETEK}

Na Slovenski univerzi za tretje življenjsko (SUTŽO) obdobje poteka več inovativnih projektov, ki ustvarjajo družbeno pomembne nove prakse, tako da postanejo rezultati raziskovalnega učenja vplivni tudi za učenje in razvoj $v$ širši skupnosti. Namen prispevka je opisati izbrane raziskovalne prakse na SUTŽO in jih interpretirati s teorijo ekspanzivnega učenja. Metodološko je raziskava zasnovana kot etnografska

Matej Urbančič, Faculty of Arts, University of Ljubljana, matej.urbancic@ff.uni-lj.si

Meta Kutin, Slovenian Third Age University

Dušana Findeisen, Slovenian Third Age University

Maja Mezgec, Faculty of Education, University of Primorska

Nives Ličen, Faculty of Arts, University of Ljubljana

Klara Kožar Rosulnik, Research Centre of the Slovenian Academy of Sciences and Arts 
raziskava z elementi fenomenološke in refleksivne raziskovalne paradigme. Ob izbranih primerih raziskovalnega učenja na SUTŽO avtorji opredelijo vplivne dejavnike za razvoj raziskovalnega učenja in doživljanje le-teh pri udeleženih v procesih raziskovalnega učenja. Ugotovitve kažejo, da ekspanzivno učenje na SUTŽO poteka kot inovativna in družbeno angažirana praksa.

Ključne besede: univerza za tretje življenjsko obdobje, ekspanzivno učenje, raziskovalno učenje

\section{INTRODUCTION}

The interest in learning as a form of participation in practice with the aim of innovating practice is far from new as it was explored by various researchers in the previous century, such as Bateson (1972), Argyris and Schön (1974), Lave and Wenger (1991). The innovative learning model was developed by Visser (2007) and Engeström (Engeström, Rantavuori \& Kerosuo, 2013). The latter designed the expansive learning model. Further insight into the connections of learning and doing has been provided by the research conducted by Tynjälä et al., who developed a model of integrative pedagogy (Tynjälä \& Gijbels, 2012; Tynjälä, Virtanen, Klemola, Kostiainen, \& Rasku-Puttonen, 2016). Ingold (2018) argues that learning by doing is always innovative; even if it imitates another activity, it includes improvisation. There are a number of different connections between innovation, practice and learning.

The research presented in this paper is focused on how development projects, doing and learning are connected in the context of older adult education at the Slovenian Third Age University (U3A). Exploratory learning emerges in a variety of settings, and the development of long-lived society has resulted in the need to generate innovative responses to the new needs of the older adults (Wacker \& Roberto, 2019; Findeisen \& Ličen, 2017; Krajnc, 2012).The theory of expansive learning has been chosen as the framework for reflection on exploratory learning.

\section{EXPANSIVE LEARNING}

The rapid increase in information, changes and uncertainty has resulted in learning becoming an increasingly unavoidable component of any doing. The abilities to acquire, design, create and use knowledge are recognised as a major asset of various organisations (Doutor \& Guimarães, 2019), including those involving older adults. Various studies are focused on the research into learning at individual and organisation levels (Zhu \& Bargiela-Chiapini, 2013; Marsick \& Watkins, 2016; Paine, 2019); they include explicit and tacit knowledge, informal and incidental learning, and also encourage the development of models for different types of learning (e.g. innovative, narrative, experiential, transformative).The complexity of modern practices has influenced the development of new theoretical models for research into learning. In the 1980s, Engeström began developing the theory of expansive learning, which emphasises learning as innovating practice and 
is characteristic of the social and historical circumstances surrounding a period of rapid change (Engeström, Rantavuori, \& Kerosuo, 2013). According to this model, innovative learning by doing depends on the sociocultural environment and the individuals' agency (Hall, Murphy, \& Soler, 2008; Engeström et al. 2013, Tynjälä et al., 2016).

The theory of expansive learning is related to the model of situated learning (McLellan, 1996; Suchman, 2003). This type of learning combines situated knowledge with everyday practices or situated actions. Learning that is placed within a cultural context occurs during participation in cultural practices and has its own "agenda", which differs from the teaching curriculum as it mostly involves informal learning. The basic framework is the concept of professional agency (Eteläpelto, Vähäsantanen, Hökkä, \& Paloniemi, 2013). Informal learning in the workplace (or wherever a subject is active) is also linked to the subject's creativity. Professional agency has mostly positive connotations for creativity and motivation, as well as a sense of satisfaction/happiness (Welzel \& Inglehart, 2010, in Eteläpelto et al., 2013).

Situated learning can be interpreted with different theories, the research presented here, however, uses the theory of expansive learning as the research focus is on innovative changing of practice. Expansive learning (Engeström, 2018) combines the cultural-historical model by Vygotsky with Bateson's systemic approach. Agency means an active attitude to reality. Humans are actors embedded in a sociocultural environment. Learning and doing are part of the sociocultural context and cannot be separated from situations. Learning and learning outcomes are not independent of the situations in which they occur, and the connection of an actor with a situation results in the production of knowledge, i.e. situated knowledge. Knowledge that is generated is a product of activity, experience, the active self and memory, as well as culture, and the historicity of an individual's biography in which the knowledge is developed and used is thus also important. Learning, as understood in this particular research, is defined as an embedded process determined by the sociocultural space, a local environment with its cultural and natural factors.

Expansive learning produces new social forms, i.e. those that do not yet exist at the beginning of an activity. The theory of expansive learning is based on the cultural-historical activity theory and implies a research methodology that allows the exploration of activity systems. ${ }^{1}$ The activity system is presented in a triangular structure including various elements. On one side of the triangle is the subject (who learns); the subject works ona selected object (substances, items, practices, individuals, groups). The subject's activity directed at the object takes places by means of cultural artefacts (tools, signs) and according to community rules. The results include professional growth, changed practices, changed ways of thinking, empowerment of groups, etc.

1 The theory of expansive learning is associated with a specific action research model - the DWR strategy (developmental work research). 
Figure 1. Activity system diagram

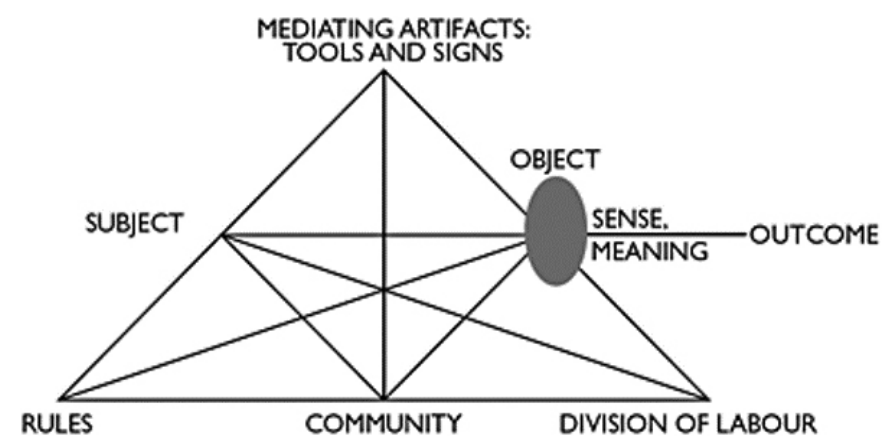

Source: Engeström, 2018, p. 48.

Rules include those governing mutual learning, the language of communication, the role of ICTs, the sequence of events, cooperation and the ethics of dialogue, specific relationships; they also include systems of norms and beliefs. The community represents other participants (in addition to the subject), researchers, learning groups, the organisation, social groups. In this model, the roles of the learner and the teacher are not separate. According to this model, the division of labour is such that all the participants are knowledge producers. Everyone occupies the role of knowledge receivers and knowledge producers, so strategies such as peer learning, mentoring and the like are used at the implementation level.

Engeström (Engeström, Rantavuori, \& Kerosuo, 2013, p. 85; Engeström, 2018, p. 63) defined the process of expansive learning through the following seven activities: (1) the first stage is the questioning of the existing practice, (2) this is followed by an analysis of the situation in which transformations of mental and practical patterns occur in order to identify the mechanisms of doing that they aim to change, (3) modelling the new solution, and (4) examining the new model, followed by (5) implementing the model, (6) reflecting on the process and evaluation. (7) The final stage is the consolidation of outcomes into a new practice (a stable form of practice). All the stages are connected in the cycle of expansive learning, ${ }^{2}$ so they do not necessarily take place in the above sequence.

Unpredictable problems imply learning that is not repetition of the known, previously acquired knowledge, nor is it reproduction of culture through the transmission of patterns and meanings - it is also creation of new cultural and social practices by transforming the existing ones or by introducing innovations, which is emphasised by the theory of expansive learning. Creativity at work is based on an adult actor's ability to perceive problems and to be able to analyse, deconstruct, and change (or surpass) established practices (routines). The definition of innovative learning in an organisation is based on Engeström (1999, p. 377), who states the following: "Innovative organisational learning

2 The cycle of expansive learning and developmental work research (DWR) are similar to the stages of design thinking and design-based research (DBR), both of which are about finding and creating new practices. 
is collaborative learning in work organisations that produces new solutions, procedures, or systemic transformations in organisational practices."

Exploratory learning occurs also as the creation of new practices at the Slovenian U3A. Much research has been undertaken into learning and training in business organisations, however, much less research has been done into innovative learning in the field of older adult education. At the Slovenian U3A, the basic study groups are study circles, some of which are involved in innovative projects. The projects are either conducted as part of a chosen study circle or independently. An example of this are international projects run by the Slovenian U3A's Research and Development Centre. The following two attributes are considered when it comes to reflection on the transfer of knowledge and the creation of new practices (new knowledge) in the local/organisational/educational environment: (a) the dynamics of knowledge and (b) the innovation of learning. These two attributes have been taken into account in the research presented in this paper, as they relate to the introduction of new practices and the changing of knowledge by supplementing quantitative growth with quality (of relationships, actions, seeking new opportunities) and fostering the flow between implicit and explicit knowledge.

\section{EMPIRICAL PART}

The research is focused on an analysis of selected examples of exploratory learning/expansive learning in practice at the Slovenian U3A. The aim is to identify the characteristics of exploratory learning ${ }^{3}$ as experienced by project participants. A further aim is to identify the factors listed by project participants as being significant for the development of exploratory learning and to identify the forms of learning and types of knowledge that emerge as part of innovative practice.

Moreover, another specific aim is to identify the characteristics of learning "under non-routine conditions", when innovations are introduced into the practices of older adult education, when routines (stable functioning of a study circle) are broken (cf. Tynjälä, 2013 , p. 16) and new practices are developed. The focus is on the micro level where learning takes place in the context of an organisation, in this particular case at the Slovenian U3A. In terms of methodology, the research was thus planned in accordance with the ethnographic method (Creswell \& Poth, 2017; Kirner \& Mills, 2019) as it involves the so-called "emic" and participatory approach (Zhu \& Bargiela-Chiapini, 2013; Giatti, 2019) - learning about phenomena through the experiences of participants involved in innovative projects.

The research plan was based on two "theoretically informed" assumptions that are grounded on the research on innovative learning in the work environment, since no similar

3 The terms innovative learning and exploratory learning are used in professional literature to refer to learning that does not constitute acquiring the already known, familiar knowledge, but rather the formation of new knowledge. The term used in this paper is "exploratory learning", as this is also the term used for this type of learning at the Slovenian U3A. 
research in the field of older adult education has been found. The first assumption was that a trans-organisational or trans-group connection (e.g. between a museum and the U3A as an educational organisation, between a botanical garden as a public place and institution and the third age university, between a bookstore and the Slovenian U3A, between Slovenian Third Age University and European third age universities) creates the potential for innovation (cf. Tuomi-Gröhn \& Engeström, 2003; Wegener \& Tanggaard, 2012; Højrup, 2012). The second assumption was that innovations occur in day-to-day activities, while practice is being innovated, and are not introduced from other research institutions.

\section{Research questions}

The aim of the research was to find out how expansive learning takes place when a group innovates a practice, and what the participants in innovative projects feel is important for the development of expansive learning.

The primary research question was developed into the following three research questions:

- What are the characteristics of expansive learning in innovative projects at the Slovenian U3A?

- How did participants in innovative projects at the Slovenian U3A experience expansive learning based on the environment?

- According to the participating actors, what influenced expansive learning?

\section{Research method}

The research was planned in accordance with the principles of activity theory. According to the activity theory, the basic research method is not a conventional laboratory experiment, but a formative experiment that combines active participation with the observation of developmental changes. The research followed the principles of reflexive methodology, the phenomenological methodological paradigm (Creswell, 2007; Creswell \& Poth, 2017), and ethnographic approaches (LeCompte \& Schensul, 2012; Price, 2013). Situated learning as informal learning is (can be) a hidden phenomenon where only a small part can be seen from the perspective of an external researcher. Therefore, an ethnographic participant observation methodwas used - in the final stage it was supplemented with data collection by means of interviews.

The ethnographic research was aimed at gaining a broader insight into the practice. The unit of research was an active group, which was viewed as an activity system according to Engström (2018). The participants were involved in research work (McNiff, 2013; McIntosh, 2010; Keane, 2003; Price, 2013), as a result of which the research is regarded as participatory. Participatory research methods were used to produce creative spaces for research and learning (Giatti, 2019).

\section{Units included in research}

The research included three cases of innovative practice that took place in three international projects. The cases were selected purposefully. In all three cases, a new form 
of social practice emerged and was incorporated into everyday activities. A number of international and national projects have so far been set up at the Slovenian U3A, introducing new practices, and the entire older adult education system has been recognised as a social innovation. ${ }^{4}$ Various innovations have been developed, such as the Festival of Knowledge and Culture in Later Life, The 11th School in Bookstore, development of strategies for using film for the purposes of active ageing and raising the awareness of stereotypes through the CinAge and RefugeesIn projects, development of a network of voluntary cultural mediators in Slovenian museums (Bračun Sova, Ličen, Findeisen, \& Kramberger, 2015), a silver economy group striving for greater social justice in this economy and fighting against the stereotypes of older adults being helpless in their old age. ${ }^{5}$ Of the many projects, three that are relevant to the research presented here were selected as research units (see Merriam, 1998, p. 61; Grbich, 2013, p. 18).

Data were collected in the following three projects:

(a) Personal Town Tours (2014; www.utzo.si/en/projekti/personal-towntours/) and activities of the study circle (project leader: M. Kutin),

(b) Promoting Third Age Education (2016-2018; www.utzo.si/en/projekti/p3ae-promoting-third-age-education/; project leader: D. Findeisen),

(c) RefugeesIn (2016-2018; www.utzo.si/en/projekti/refugeesin/; project leader: D. Findeisen).

The Personal Town Tours project was set up on the basis of an identically-titled EU project, which involved partners from Bulgaria, Romania, France, Germany, Italy and Slovenia. The focus of the project was establishing sightseeing town routes based on the preferences of project participants.

The project partners in the project titled Promoting Third Age Education were from Lithuania, Latvia, Spain and Slovenia. The main aim of the project was to contribute to the professionalisation of the field of older adult education.

The RefugeesIn project was a continuation of the CinAge project - European Cinema for Active Ageing. The aim of the project, which included partners from Slovenia, Portugal, Germany, Ireland, Italy and Greece, was to raise awareness of the derogatory and stereotypical treatment of older adults and migrants.

\section{Data collection and processing}

Data collection took place over different time periods between the academic years 2013/14 and 2017/18. Various data collection methods were used and the principles of newer ethnographic approaches, as described by Grbich (2013, pp. 55-69), were

4 In 2011, A. Krajnc and D. Findeisen received the Social Innovation Award (SPIRIT Slovenia - Public Agency for Entrepreneurship, Internationalisation, Foreign Investments, and Technology). In 2012, the Association for Third Age Education was presented with a national education award.

5 The listed projects are presented in more detail on the Slovenian U3A's website:http://www.utzo.si/en/ projects/ 
followed. Participant observation, unstructured interviews and document analysis were all used - the latter is available on the website of the Slovenian U3A. The researchers participated during the course of all three projects, as well as in various product presentations (e.g. the presentation of a brochure as part of Personal Town Tours project). Ethnographic research is a creative experience and the "objects" of research are the subjects with whom a relationship is established. The epistemological position adopted in data collection followed the "surrender-and-catch" principle (Gherardi, 2012), which means that the researcher surrenders to whatever goes on and is committed in the relationship to it. The data were recorded in the form of field notes. They were processed by means of the textual analysis method and thematic sets were formed. The data were arranged according to the principles of classification (the material was categorised) using deductive and inductive approaches and taking into account the theory of expansive learning.

A preliminary thematic analysis was performed following the principles of grounded theory (Denzin \& Lincoln, 2011). Although the research question design was informed by theory, the analysis was not focused on comparing empirical data with established theories (or definitions), as there are very few such theories when it comes to the field of older adult education. The coding was open and was done by attaching concepts (codes) for each individual activity in the field notes.

In addition to observation, two in-depth interviews were conducted in 2018. The two interviewees were selected purposefully - they both have more than ten years of experience working with older adults, they are both highly educated in the field of social sciences and humanities, they both work as mentors of study circles at the Slovenian U3A and they were both involved in the selected research and development projects. One of the two interviewees was involved in all three projects and the other in one of them.

\section{FINDINGS}

The findings are presented based on the developed research questions and topics. The description of the phenomena is accompanied by verbatim notes taken during the fieldwork and the interviews - the notes are marked using indentations and are italicised. The following three topics, which follow the research questions, have been formed on the basis of empirical data: characteristics of expansive learning, experience of expansive learning, influences on expansive learning.

\section{CHARACTERISTICS OF EXPANSIVE LEARNING}

In this part, the answer to the first research question is provided: What are the characteristics of expansive learning in innovative projects at the Slovenian U3A?

The first set of answers reveals that the cycle of expansive learning emerged in all three projects, that different forms of learning have been developed, that different learning 
strategies have been used and that different types of knowledge have been produced. The answer to the first question is provided through the following three sub-topics:

(a) expansive learning as part of innovation,

(b) forms of learning,

(c) types of knowledge and wisdom.

\section{Expansive learning as part of innovation}

The basic assumption was that trans-organisational or trans-group networking creates the potential for innovations (Wegener \& Tanggaard, 2012; Højrup, 2012). When it comes to the Slovenian U3A, the observations and interviews suggest that this is partly true since most of the innovations originate from the Slovenian U3A.

The fact that we want to adapt to other institutions, i.e. to the way they work, makes us take steps towards them. However, other institutions don't necessarily - in fact, usually this is not the case - take any steps in our direction. When we work together, however, this does bring about some change. Usually innovations come entirely from our side. There is a bit more collaboration when it comes to international projects where we conceive and plan the project together, but then again, only some of the project partners - one or two of them - are actively involved. Many of our innovations are developed by the process of analogy, by modifying the existing practice and taking into account the given frameworks. For instance, by recognising a certain need, through calls for tenders, the questions we receive, the need to change whatever already exists, and, most of all, by reading various studies and daily newspapers, by watching foreign TV programmes, on the basis of identified and anticipated social problems, such as migrants even before they made it over here, or a higher retirement age and social exclusion of older adults. Learning from real, actual problems leads to innovative learning. [Interview 1]

Expansive learning is not only related to new technology, on which research is generally most often focused (Hackel \& Klebl, 2014), and is also present at the Slovenian U3A. Professionals working in fields where relationships and communication play an important role, such as in older adult education, are confronted with the stories of people that are part of the paradoxes of insecurity in the modern world and their work must respond to people's needs rather than merely following a specific educational programme (curriculum). Innovations are developed at different levels of older adult education (in groups, at the level of the entire organisation), as well as through the impacts on the wider cultural environment.

Expansive learning comes from a certain deficit, a lack of something or the urge to innovate. The first of the challenges is presented when facing problems that have arisen as a result of established routine practices no longer being suitable. Mentors need to develop new professional expertise, emotional abilities and professional practice that allow them to find new knowledge that will respond to a perceived problem. 
The second challenge is posed by the need to bring innovations into practice as leaders explore how to develop new programmes. Older adult education is a new activity and can thus not merely respond to explicitly expressed needs, as these needs do not yet exist in the environment in the first place; rather, it needs to use professional knowledge to identify opportunities for proximal development (see Engeström \& Sannino, 2010) and develop innovative practices accordingly. The learning that occurs in these situations is still part of experience and doing, and is based on agency. However, it is not driven by a deficit - rather it is part of innovation. All three projects were based on a research relationship to the phenomena (the town as experienced by older adults, migrations, older adult education). None of the three cases involved "urgent deficit-related problems"; they were about introducing innovations aimed at developing new models and not at solving a particular problem.

\section{Forms of learning}

Unintentional and informal learning took place as an accompanying part of doing. In older adult students, informal learning was not recognised until after the projects had already been completed, and some processes were recognised as learning retrospectively through reflection on the processes. Intentional learning also occurred, specifically in the form of the following strategies:

(a) Self-guided learning by means of various printed resources (books) and watching TV shows, self-guided learning through a self-analysis of one's experiences (talking to oneself, reflecting on experiences, talking about experiences with friends), browsing the internet, asking in forums (they spent a lot of time searching for similar cases online, which indicates a high level of motivation for learning/the project);

(b) peer mentoring by means of talking to others and emailing them about the project content (e.g. they called their colleagues to ask them about the problems they are facing in the projects);

(c) trial and error: trial-and-error learning was not learning in the sense of "training", but rather double-loop learning or deutero learning, where an individual learns the rules and then modifies them, which is a common type of organisational learning (see Leicher, 2013; Findeisen, 2013).

The identified forms of learning are classified as informal and non-formal forms of learning, which has been confirmed by other studies in the field of workplace learning (e.g. Tynjälä, 2013; Engeström, 2013). One of the forms of learning was cooperative learning, where the entire project team acted as a learning group. Another identified learning strategy were study tours as part of which the groups met up with other international groups.

\section{Types of knowledge}

Expansive learning develops different types of knowledge and connects all types of knowledge, which leads to new ideas and practices. The concept of knowledge includes four integrated components (Tynjälä \& Gijbels, 2012; Findeisen \& Ličen, 2017), all of 
which were developed in the projects that were the subject of observation: conceptual knowledge, practical and experiential knowledge, self-regulative knowledge and sociocultural knowledge. The one characteristic that stands out in older adults' projects is wisdom. Older adults are not "information junkies", as pointed out by Moody as early as 1986 (Moody, 1986, p. 135), but rather they develop intertwined systems of knowledge, which are best referred to as wisdom. Wisdom is understood as a balanced system of different forms of knowledge: narrative, intuitive, experiential, conceptual, rational and sociocultural. In innovative projects, a complex of cognitive, reflexive and affective elements is developed. Ardelt refers to it as wisdom (Ardelt \& Jacobs, 2008), which leads to conscious ageing and positive ageing, both of which promote expansive learning at a subjective level as a process of reinventing oneself.

The way different types of knowledge are intertwined is indicated by the field notes below.

The first meeting with the future project participants took place a week before leaving for Venice and the Università della Terza Età Mestre, an institution that has a few characteristics in common with Slovenian Third Age University. The responses of future participants were easy to predict as they reflected the rather common fears of Slovenians. "I won't be able to do it, foreigners are better than us," was the unspoken underlying thought. D. F. encouraged them: "Tell me at least one 'foreigners' trait that would make them better than you." The responses were emotional and unreasonable. It mattered that the co-founder of the Slovenian U3A was present at this meeting. Her age, experience and position reassured them to some extent, so they stopped asking so many questions about what they would be doing, how they would work, what the language of communication would be, and they stopped hesitating. It was, however, not possible to provide detailed and comprehensive answers, as they concerned exploratory learning, which always involves a number of unknowns. The university representative told them that she was not surprised, as she had expected these sort of responses. In the end she added jokingly, "You know how to do it and you'll be the best as usual. We, Slovenians, are always the best among foreigners ..." [Field Notes 2017; emphasised by the authors]

For a long time, they couldn't understand that they wouldn't attend any lectures, that they would combine their new knowledge with the previously acquired disciplinary knowledge, that they would construct it together as new knowledge. They expected that they would be able to remain knowledge recipients, the sort of recipients that add some of their experiential insights for illustration purposes from time to time, offering them to their mentor and fellow students. [Interview 1, emphasised by the authors]

The knowledge produced in innovative projects impacts the environment, as well as the personal attitude to one's own ageing and personal biography. Understanding knowledge 
is important for every project. If, for instance, cultural heritage is preserved/understood not only through scientific approaches, but also through memories (the bearers of experience), volunteers working as tourist guides can serve as a new means for generations to meet. If the creation of town tours is viewed as a creation of an environment of existence, cultural mediators and narrative knowledge gain in importance. If a town is interpreted not only through formal professional records (urbanism, architecture, demography, etc.), but is understood as whatever one feels in it, an innovative project may be different than if it is created only on the basis of scientific (conceptual, theoretical) knowledge.

\section{EXPERIENCE OF EXPANSIVE LEARNING}

This part provides the answer to the second research question: How did the participants in the innovative projects at the Slovenian U3A experience expansive learning based on the environment?

The answer was formulated using the following subtopics: satisfaction, commitment/ belonging.

Satisfaction with innovative learning was observed in all the cases, which was confirmed by the two interviewees. A similar observation was made by Eteläpelto et al. (2013), who noted that work satisfaction develops during innovative projects.

During its journey, the group experiences some wonderful moments when, after a period of searching, the results of its work gain recognition by outsiders: public appearances, participation in a conference, an invitation to make a public appearance in a foreign environment, preparation of a guide book and an exhibition, journalists' interest, newspaper articles about them, radio broadcasts, invitations to new projects. Appraisal by the public plays an important role in the process of knowledge acquisition. The public and the individuals they meet ensure that the knowledge is spread and enhanced, that there is even more exploratory learning. Both 'researchers' and other individuals in the environment get excited about it. [Interview 1]

Older adult students described learning as "an internal force that is part of every human being" and said that learning was intertwined with personal biographies. New knowledge became part of their lives. The second interviewee made similar observations.

"Learning cannot be separated from life, they go hand in hand," they [students] said. The same thing is clear from the large amount of emails, text messages, and repetitions of the tour route. A student sent an email to the other students in her group, saying, "I'm now testing our research topic on café life in practice. And I'm sending you a photo." Another student wrote the following: "I did a bit of tidying up and decluttering around the house and found some books on the topic I know you'd be interested in. I have them in my car if you'd like them." 
And a third student said, "I'll try to make arrangements for the project results to be displayed at our local library. I'd like others to see what we have seen." [Interview 2]

They emphasised the development of their own identity (sense of self, self-image and sense of belonging to the community), which points to the importance of self-regulatory knowledge formed through the experience of innovative practice.

The knowledge we gain in projects is primarily for the sake of innovation, for a project. But at the same time this makes me feel better, I feel I'm doing well, said M. P. [Field Notes 2018]

In projects carried out at the Slovenian U3A, the groups that were introducing innovations were independent and "posed no threat" to anyone, unlike in the work environment, where some colleagues may be forced to break out of established routines or rigid practices when an innovation is introduced. Innovative projects have been well received both at the Slovenian U3A and in the milieu, which gave the students satisfaction. Individuals or small groups that have innovative ideas and articulate many ideas for change are often not well received in their (work) environment. Højrup (2012), Toumi-Gröhn and Engeström (2003) propose organising learning teams as part of which learning can take place. These teams provide psychological security/trust, share a common field of experience, create new knowledge, and then test it. An example of such teams are research study circles at the Slovenian U3A.

It can be concluded that innovation must be regarded as interaction. It depends on mutual relationships and the culture within an organisation. Innovations are a form of participation in which older adult students take the initiative to develop change, so it is important for them to feel that they can act on their own initiative. In the development of innovative projects, the affective element ("a good feeling") has been provided in a number of ways. Innovative projects were well received by the media (radio broadcasts, newspaper articles). The Slovenian U3A follows the principle that all activities, in particular innovative activities taking place in a field with less social power (such as older adult education), should also be promoted in the media. Expansive learning is part of the cultural environment, and it is therefore desirable, according to the theory of learning used, that a wider public is informed about the innovations introduced in older adult education. This element also affects the identification of the older adults with the Slovenian U3A.

Practice innovation is related to professional commitment and dedication to the work of the Slovenian U3A, as the mentors' and students' statements reveal that much of the learning took place outside working hours, i.e. outside the individuals' time that is officially intended for work at the Slovenian U3A. In the cases researched, it was of crucial importance that the actors in the study circles understood and trusted one another.

Learning took place as: 
(a) the changing of programmes, which could be understood as the transformation of cultural objects and that of knowledge transfer tools;

(b) proximal development (the participants reported changes in knowledge (expertise) as well as self-feelings (identity)); all learning took place through doing and was based on agency and reflection;

(c) new ways of network building (e.g. the content of socialising becomes different, the motives for socialising are related to innovative projects).

\section{INFLUENCES ON EXPANSIVE LEARNING}

The answer to the third research question on what influenced expansive learning in the opinion of the participating actors is provided through the subtopics on the rules and activities within the community. The subtopics include the understanding of older adult education and active ageing, personal motivation and understanding learning as a biographical process. According to older adult students, the following is important for expansive learning:

(a) Understanding of older adult education and the associated active ageing and lifelong development

Older adult students view older adult education as an integral part of their development, including professional development, as noted in the following statements (summarised from the field notes taken during short conversations with the participants):

If you see getting old merely as deteriorating, it's difficult.

I moved to Ljubljana a few years ago, but it's taken me until now that I'm working with you to feel like I'm becoming a local.

When I took visitors around Ljubljana, the atmosphere was really great. You could feel mutual enthusiasm, which confirms that we [older adults, authors' note] can offer something that 'routine guides' can't. [Field Notes 2018]

The conception of identity as something that individuals accept (as a social role) at the beginning of life and then "carry" it with them faded when new understandings of identity as a process emerged. Unless older adult students develop an idea of themselves and their identity as something that develops even in old age, they are not likely to be favourably inclined towards innovative learning.

\section{(b) Personal motivation and personal goals}

To persist in the search of the new requires personal motivation, which older adult students in innovative projects display in different ways. If a learning subject is unable to accept the risk, they will prefer to follow routine when learning and they will want to be told by others about a strategy that has previously proven efficient. When it comes to innovative projects, however, older adults create new knowledge. The second interviewee had the following to say in relation to this: 
We have fun (we can experiment) while doing this, no one can stop us after all, right?

You can make even more use of me in these tasks, a student wrote to his mentor.

I know this topic doesn't quite fit in with the project concept, but I've always been interested in it and would like to work on it. We'll be able to incorporate it somehow, right? [Interview 2]

\section{(c) Understanding learning as a biographical process}

An older adult student said:

During my many years working in television, I developed a bit of a feeling for composition and detail. Now I'm trying my hand at photography. When I took the very first photos for our project, I was still using an ordinary camera. When I replaced my old mobile, I chose a new one, a so-called smartphone because it's, among other things, more practical for taking photos and I can always carry it on me. Now I'd like to learn a photo editing programme. [Interview 2]

It's important that you achieve something when everyone else is telling you that there is no point in it, you have retired after all! It's important for you to achieve something in a new community and in a new field. [M. P., Field Notes 2018]

Participants in the projects where expansive learning was studied as part of this research are convinced that learning is a lifelong process and that each of us learn all the time. Another difference lies in whether learning is viewed as an individual process (one is responsible for everything on one's own) or as a social process depending on the sociocultural environment. In the groups involved in the projects, both were observed.

The above elements are part of the activity system structure that influence expansive learning. They make up systems of community rules and practices. The environment in which expansive learning takes place is important. At the Slovenian U3A, innovative projects enjoy the support of the management, which is all about promoting innovation.

Innovative projects involve the activities of acquiring, creating and using knowledge. In the networks of actors (students, mentors, researchers, management), all these activities are intertwined without any role hierarchy.

\section{CONCLUSION}

The theory of expansive learning is an appropriate choice for interpreting learning in development projects carried out at the Slovenian U3A. Learning is reflected at different levels and through different types of knowledge. It has been found that expansive learning in the researched projects was influenced by factors within the environment at the level of 
individuals (students, mentors, and researchers), the group (study circle) and the organisation (Slovenian U3A).

Project activities, as a social innovation, have influenced the development of a wider community. The collaboration between the Faculty of Arts at University of Ljubljana, and the Slovenian U3A resulted in a study course titled Older Adult Education, which was influenced by all three aforementioned projects. Tours of Ljubljana were set up, round tables were organised and films were made with the aim of raising awareness of migration. Learning in innovative projects, which takes place under the expansive learning scheme, thus introduces important innovations into the environment.

Introducing innovations through expansive learning can be understood as a period of transition during which a number of abilities turn out to be important, i.e. the ability to explore one's own practice and adapt to unpredictable situations, plan one's own work, learn by means of self-guided learning and create new knowledge, with all the actors within the system also acting as knowledge producers. All three projects led to the formation of explicitly coded knowledge (publications in professional and scientific periodicals, undergraduate and master's theses). As pointed out by all research participants, the snowball effect is distinct in expansive learning. It generates new learning: when a project is carried out in a relaxed atmosphere, these results in a wealth of ideas for new projects. Innovative projects have been well received internationally. Expansive learning has led to raising awareness of older adults' opportunities for active ageing through socially engaged education and socially engaged art.

\section{REFERENCES}

Ardelt, M., \& Jacobs, S. (2008). Wisdom, integrity and life-satisfaction in very old age. In M. Cecil Smith, \& T. G. DeFrates-Densh (Eds.), Handbook of Research on Adult Development and learning (pp.73-759). New York: Routledge.

Argyris, C., \& Schön, D. (1974). Theory in Practice. San Francisco: Jossey-Bass.

Bateson, G. (1972). Steps to an Ecology of Mind. Chicago: Chicago University Press.

Bračun Sova, R., Ličen, N., Findeisen, D., \& Kramberger, U. (2015). Personal experience of education for formaly organised older volunteering. Review of European studies, 7(11), 166-174.

Creswell, J. (2007). Qualitative Inquiry and Research Design: Choosing among Five Approaches. London: Sage.

Creswell, J. W., \& Poth, C. N. (2017). Qualitative Inquiry and Research Design. London: Sage.

Denzin, N. K., \& Lincoln, Y. S. (Eds.). (2011). The Sage Handbook of Qualitative Research. Los Angeles: Sage.

Doutor, C., \& Guimarães, P. (2019). Adult Education and Lifelong Learning Policies: An analysis of Greece and Portugal. Andragoška spoznanja, 25(1), 15-31.

Engeström, Y. (1999). Innovative learning in work teams: Analyzing cycles of knowledge creation in practice. In Y. Engeström, R. Miettinen, \& R. L. Punamäki (Eds.), Perspectives on activity theory (pp. 377-404). Cambridge: Cambridge University Press.

Engeström, Y., \& Sannino, A. (2010). Studies of expansive learning: Foundations, findings and future challenges. Educational Research Review, 5(1), 1-24. 
Engeström, Y., Rantavuori, J., \& Kerosuo, H. (2013). Expansive Learning in a Library: Actions, Cycles and Deviations from Instructional Intentions. Vocations and Learning, 6(1), 81-106.

Engeström, Y. (2018). Expansive learning: toward an activity-theoretical reconceptualization. In K. Illeris (Ed.), Contemporary Theories of Learning (pp. 46-65). New York: Routledge.

Eteläpelto, A., Vähäsantanen, K., Hökkä, P., \& Paloniemi, S. (2013). What is agency? Conceptualizing professional agency at work. Educational Research Review, 10(2013), 45-65.

Findeisen, D. (2013). O povezljivosti elementov različnih načinov učenja, metod in znanja. Andragoška spoznanja, 19(4), 90-95.

Findeisen, D., \& Ličen, N. (2017). Konceptualne smernice za izobraževalce na področju izobraževanja starejših. Ljubljana: Slovenska univerza za tretje življenjsko obdobje.

Giatti, L. L. (2019). Participatory Research in the Post-Normal Age. Cham: Springer.

Gherardi, S. (2012). How to conduct a practice-based study: Problems and methods. Northampton: Elgar.

Grbich, C. (2013). Qualitative Data Analysis. London: Sage.

Hackel, M., \& Klebl, M. (2014). The Double Path of Expansive Learning in Complex Socio-Technical Change Processes. Outlines. Critical Practice Studies, 15(1), 4-27.

Hall, K., Murphy, P., \& Soler, J. (Eds.). (2008). Pedagogy and Practice: Culture and Identities. London: Sage.

Højrup, S. (2012). Employee-Driven Innovation: A New Phenomenon, Concept and Mode of Innovation. In S. Højrup, M. Bonafous-Boucher, C. Hasse, M. Lotz., \& K. Møller (Eds.), Employee-Driven Innovation: A New Approach (pp. 3-33). New York: Palgrave Macmillan.

Ingold, T. (2018). Anthropology and/as Education. London: Routledge.

Keane, W. (2003). Self-Interpretation, Agency, and the objects of Anthropology: Reflections on a Genealogy. Comparative Studies in Society and History, 45(2), 222-248.

Kirner, K., \& Mills, J. (2019). Doing Ethnographic Research: Activities and Exercises. Thousand Oaks: Sage Publications.

Krajnc, A. (2012). Older Adults as a Special Learner Audience. Andragoška spoznanja, 18(3), 25-37.

Lave, J., \& Wenger, E. (1991). Situated Learning. Legitimate Peripheral Participation. Cambridge: Cambridge University Press.

LeCompte, M. D., \& Schensul, J. J. (2012). Analysis \& Interpretation of Ethnographic Data. Lanham: AltaMira Press.

Leicher, V., Mulder, R., \& Bauer, J. (2013). Learning from Errors at Work: A Replication Study in Elder Care Nursing. Vocations and Learning, 6(2), 207-220.

Marsick, V. J., \& Watkins, K. E. (2016). Informal and Incidental Learning in the Workplace. New York: Routledge.

McIntosh, P. (2010). Action Research and Reflective Practice. Creative and visual methods to facilitate reflection and learning. London: Routledge.

McLellan, H. (Ed.). (1996). Situated Learning Perspectives. Englewood Cliffs: Educational Technology Publications.

McNiff, J. (2013). Action Research: Principles and Practice. New York: Routledge.

Merriam, S. B. (1998). Qualitative Research and Case Study Applications in Education. San Francisco: Jossey-Bass.

Moody, H. R. (1986). Late life learning in the information society. In D. A. Peterson, J. E. Thornton, \& J. E. Birren (Eds.), Education and Aging (pp. 122-148). Englewood Cliffs: Prentice Hall.

Paine, N. (2019). Workplace Learning. London: Kogan Page. 
Price, F. (2013). Proximal ethnography: 'inside-out-side' research and the impact of shared methaphors of learning. Teachers and Teaching, 19(6), 559-609.

Suchman, L. (2003). Organizing Alignment: The Case of Bridge Building. In D. Nicolini, S. Gherardi, \& D. Yanow (Eds.), Knowing in organization: A Practice-Based Approach (pp.187-203). London: M. E. Sharpe.

Tuomi-Gröhn, T., \& Engeström, Y. (Eds.). (2003). Between School and Work: New perspectives on Transfer and Boundary-Crossing. Oxford: Emerald Group Publishing.

Tynjälä, P., \& Gijbels, D. (2012). Changing world - changing pedagogy. In P. Tynjälä, M.-L. Stenström, \& M. Saarnivaara (Eds.), Transitions and transformations in education (pp. 205-222). Dordrecht: Springer.

Tynjälä, P. (2013). Toward a 3-P Model of Workplace Learning: a Literature Review. Vocations and Learning, 6(1), 11-36.

Tynjälä, P., Virtanen, A., Klemola, U., Kostiainen, E., \& Rasku-Puttonen, H. (2016). Developing social competence and other generic skills in teacher education: applying the model of integrative pedagogy. European Journal of Teacher Education, 39(3), 368-387.

Visser, M. (2007). Deutero-learning in organizations: A review and a reformulation. Academy of management Review, 32(2), 659-667.

Wacker, R. R., \& Roberto, K. A. (2019). Community Resources for Older Adults. Programs and Services in an Era of change. Los Angeles: Sage.

Wegener, C., \& Tanggaard, L. (2012). The concept of innovation. Studies in Continuing Education, 35(1), 82-101.

Zhu, Y., \& Bargiela-Chiapini, F. (2013). Balancing Emic and Etic: Situated Learning and Ethnography of Communication in Cross-Cultural Management Education. Academy of Management learning \& Education, 12(3), 380-395. 